UDC 631.52:633.31:631.67

R. Vozhehova, corresponding member of NAAS, Doctor of Agricultural Sciences

O. Tyshchenko, Candidate of Agricultural Sciences

Institute of Irrigated farming, NAAS

\title{
CREATION AND ASSESSMENT OF BREEDING MATERIAL OF LUCERNE WITH THE HEIGHTENED LEVEL OF AZOTFIXATION
}

The purpose. To create and assess initial material of Lucerne on a complex of economic valuable attributes for further their use in selection process. Methods. Inbreeding, polycross-method and artificial crossing. They assessed plants grown in sandy substratum and field conditions. Results. Differentiation of synthetic selection material (S1 and S2) is made. They selected back-crossed and inbred progeny with the maximum productivity indexes, high level of morphological characteristics of root system: diameter of a root, its mass, volume of root system, and nitrogenase activity. Inbreeding in the second generation irrespective of constitution of root system of initial forms promoted increase of number of plants with rod-branched root system. Factorial attributes which can be used as criteria of selection on productivity of azotfixation are specified. Conclusions.

Comprehensive assessment of collection material in conditions of irrigation has allowed to select forms which are of interest for selection of new high-yielding varieties of Lucerne with different attributes and properties, includinghigh symbiotic azotfixation. Marker attributes are determined which at the first stages of selection process allow to take forms with the maximum indexes of azotfixation.

Key words: Lucerne, population, inbreeding, polydistributing frame, root system, productivity, azotfixation, inheritance.

Among the perennial forage legumes most popular and widespread in the world is alfalfa. The practical value of alfalfa is not limited to its feeding value. It also performs other important functions, agronomic, biological, agroecological. Of great importance are also reproduction of soil fertility and enriching it with nitrogen. This issue is urgent in view of the fact that in recent years agriculture of Ukraine has operated under negative balance of humus, nitrogen, phosphorus and other factors [1], 80-90\% of arable land being degraded. [2]. Alfalfa is a good precursor for many crops.

The creation of new varieties is always focused on the problem of a valuable base line as an inexhaustible source of genetic diversity of characteristics and properties. This is the most crucial stage of the selection process that determines the final result of the breeder.

Higher rate biological nitrogen fixation makes it possible to minimize the use of chemical fertilizers, their production being a power-intensive, expensive and dangerous for the environment process. 
The object of the research was to obtain and assess an alfalfa base line for its involvement in the selection process of breeding new varieties with higher rates of nitrogen fixation and the use of different selection methods.

Materials and methods. Genetically diverse donors and sources of valuable characteristics and properties served as the base line. These are varieties of domestic and foreign selection which often have a single or rarely a set of beneficial properties. They include varieties from the United States (Teton, Progress) characterized by macrobiosis, rapid regrowth, high growth; those from France the F-34 variety characterized by high seed productivity; from Yugoslavia, Ecuador varieties characterized by several hay harvests, rapid regrowth; from Italy the Florida variety characterized by good tillering; from Canada the Rambler variety characterized by winter hardiness and drought resistance, extensive root system which allows to tolerate trampling animals; from Australia the Cancreep variety characterized by rapid regrowth after harvesting, resistance to root rot and leaves fungal diseases. Among the varieties of the former USSR selection the most valuable for the areas of irrigated agriculture are such varieties as Veselopodolyanska 11 (Veselopodolyanska Research Station, Poltava region) characterized by good tillering and winter hardiness, Yigera 118 (Lithuanian Agricultural Research Institute) which is characterized by high winter hardiness. Considering the value of wild forms that have a complex of most important properties and features, the selection process involves different kinds of wild alfalfa: Medicago tyanschanica Vass. (2n = 32); M. glutinosa M.B., $(2 \mathrm{n}=32)$; colorful M. polychroa Grossh., $(2 \mathrm{n}=32) ;$ M. agropyretorum Vass., $(2 \mathrm{n}=32) ; M$. quasifalcat Sinsk. $(2 \mathrm{n}=16)$ and $M$. coerulea Less. $(2 \mathrm{n}=16)$ which have been transferred to the tetraploid level.

In the studies of nitrogen-fixing ability use was made of nitrogen-free media (sand culture) against inoculation and humidity at 70-80\%. The complete plant analysis was made in the second harvest at early flowering stage taking into account the plant height, root system form, its volume, architectonics, the number of nodules and their fractional composition, the number of stems and the weight of the plant root and top. Nitrogenase activity was determined by gas chromatograph Chrom 5. Under field conditions the populations were assessed in the nursery with single-standing plants, space between rows being $15 \mathrm{~cm}$ and space between plants being 3-5 $\mathrm{cm}$. The analysis was conducted for each plant separately taking into account plant height, tillering, the weight of plant root and top.

To create alfalfa synthetic material, inbreeding, polycross and artificial crossing methods were used.

Results of research. The long-term research by the Institute of Irrigated Farming, NAAS, gives cause to label the existing alfalfa gene pool from various countries as the varieties formed in the natural evolution process or due to selection, according to the classification by P.O. Lubenets. Basically it is alfalfa of sowing type (60.9\%), less mutable alfalfa (26.2\%), yellow alfalfa $(7.4 \%)$, blue alfalfa (1.2\%) and $1.1 \%$ other varieties such as pink, multicolored, Adhesive, Tien Shan. After a comprehensive assessment of several varieties selected abroad and in other USSR institutions in the irrigated area, some forms have been identified that 
are of interest as the base line. However, the high heterozygosity of alfalfa, due to cross-pollination, causes a large variability among plant varieties as to their characteristics such as nitrogen-fixation, root system form, root characteristics. Genotypic differentiation of the base lines varying in heredity is made possible by inbreeding. The polycross method helps to combine the best genotypes. The method of inbreeding involves the disclosure of many forms the culture possesses and leads to the emergence of a large variety of morphological features and forms according to the rate of regrowth, tillering, stem and root characteristics, the nature of leaves, their number, the duration of the vegetative period, resistance to cold, resistance to disease [3].

In order to differentiate the obtained synthetic selection material, a shallow inbreeding $\left(\mathrm{S}_{1}\right.$ and $\left.\mathrm{S}_{2}\right)$ was performed. Part of this material was included in the artificial and saturant crosses. Thus, seven populations have been obtained: Syn (c) $S_{1} B C_{1}$, Syn (c) $S_{1}$ at free pollination, Syn (c) $S_{2}$, Syn downy $S_{1} /$ Syn (c) $S_{1} F_{2}$, Syn (c) $S_{1} /$ Syn downy $S_{1} F_{2}$, Syn downy $S_{2}$, Syn downy $S_{1}$ at free pollination.

The results of the analysis of the data obtained show that in the studied numbers the verdurous and air-dry masses weight varies from 16.0 to 22.7 and 5.7 - $7.5 \mathrm{~g} /$ plant, respectively (Table 1).

1. Characteristics of alfalfa population according to its economically beneficial properties in sand culture (2013-2015)

\begin{tabular}{|c|c|c|c|c|c|c|c|c|c|}
\hline \multirow[b]{2}{*}{ № } & \multirow[b]{2}{*}{ Genetic origin } & \multirow[b]{2}{*}{ 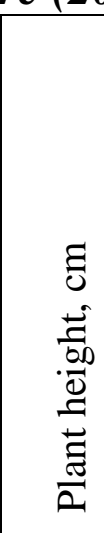 } & \multirow{2}{*}{ 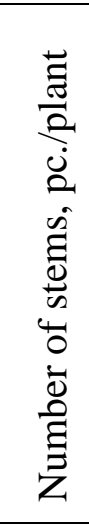 } & \multicolumn{2}{|c|}{$\begin{array}{l}\text { Plant } \\
\text { weight, g }\end{array}$} & \multirow[b]{2}{*}{ 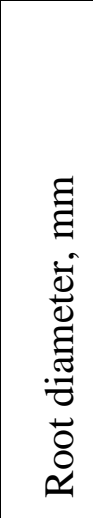 } & \multirow[b]{2}{*}{$\begin{array}{l}\bar{\Xi} \\
8 \\
\Xi \\
\Xi \\
0 \\
8 \\
0 \\
0 \\
\alpha\end{array}$} & \multirow[b]{2}{*}{ 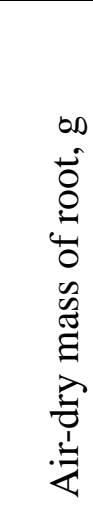 } & \multirow{2}{*}{ 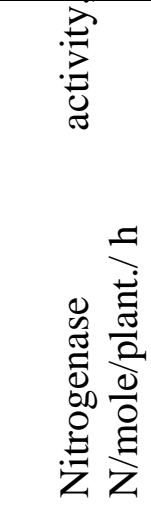 } \\
\hline & & & & 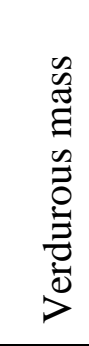 & 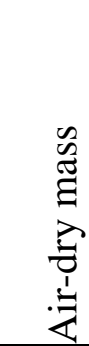 & & & & \\
\hline 1 & $\operatorname{Syn}(\mathrm{c}) \mathrm{S}_{1} \mathrm{BC}_{1}$ & 28.2 & 5.0 & 22.7 & 7.6 & 6.3 & 6.58 & 6.5 & 29156.6 \\
\hline 2 & Syn (c) $\mathrm{S}_{1}$ at free pollination & 29.0 & 4.6 & 21.4 & 6.9 & 6.2 & 6.30 & 5.6 & 26715.7 \\
\hline 3 & Syn (c) $\mathrm{S}_{2}$ & 28.5 & 4.3 & 16.0 & 5.7 & 5.8 & 5.70 & 5.3 & 27075.7 \\
\hline 4 & Syn downy. $\mathrm{S}_{1} / \mathrm{Syn}(\mathrm{c}) \mathrm{S}_{1} \mathrm{~F}_{2}$ & 30.2 & 4.7 & 21.0 & 7.5 & 6.2 & 6.00 & 5.9 & 23710.4 \\
\hline 5 & Syn downy. $S_{1}$ at free pollination & 30.0 & 4.5 & 20.0 & 7.1 & 6.0 & 6.00 & 5.7 & 21027.4 \\
\hline 6 & Syn downy. $S_{2}$ & 30.0 & 4.4 & 16.2 & 5.9 & 6.0 & 6.00 & 5.5 & 14583.5 \\
\hline 7 & Syn(c)/Syn downy.S $\mathrm{F}_{2}$ & 31.0 & 4.9 & 21.2 & 7.1 & 6.3 & 6.60 & 6.2 & 26302.5 \\
\hline \multicolumn{2}{|c|}{ Population average } & 29.6 & 4.6 & 19.8 & 6.7 & 6.1 & 6.20 & 5.8 & 24082.8 \\
\hline
\end{tabular}

The maximum productivity characteristics were shown by backcrossed and inbred descendants: $\operatorname{Syn}(\mathrm{c}) \mathrm{S}_{1} \mathrm{~B} \mathrm{C}_{1}$, Syn (c) $\mathrm{S}_{1}$ at free pollination, hybrid populations Syn downy $S_{1} / \operatorname{Syn}(c) S_{1} F 2$, Syn (c) $S_{1} /$ Syn downy $S_{1} F_{2}$. Backcrossed descendants of Syn (s) $S_{1} B C_{1}$ and the hybrid population of Syn (s) $S_{1} /$ Sin downy $\mathrm{S}_{1} \mathrm{~F}_{2}$ also had higher rates than the population average as to morphological features of the root system: the root diameter $(+3.3 \%)$, its weight $(+6.9-12.0 \%)$, the volume of the root system $(+6.1-6.5 \%)$. They were characterized by a high 
level of nitrogen activity (+21.1-9.2\%) in relation to the population average. In addition, the inbred descendants of Syn (c) $S_{1}$ and Syn downy $S_{1}$ exceeded the populations with deeper inbreeding (Syn (c) $S_{2}$, Syn downy $S_{2}$ ) in such characteristics as plant height, number of stems per plant, verdurous and air-dry mass, which testifies to the depression they experienced. Especially sharply the level of nitrogenase activity decreased (by 144 times) in Syn downy $S_{2}$ compared to the inbred descendants of Syn downy $S_{1}$ at free pollination. The assessment of breeding material under field conditions shows that high productivity is characteristic of backcrossed descendants of Syn (c) $S_{1} B C_{1}$ as well as the second inbreeding descendants Syn (c) $S_{2}$, Syn downy $S_{2}$ in contrast to the data obtained in the sand culture. According to the yield of verdurous and air-dry masses they exceeded the population average by $12.7-43.0 \%$. The first two populations were also distinguished by the number of stems per plant - 13.5-13.6 versus 10.2 in the population average. According to this breeding material estimates in various forage plant nurseries, the population of Syn (c) $S_{1} B C_{1}$ formed the verdurous mass yield of $12.85 \mathrm{~kg} / \mathrm{m} 2$ in the second year of herbage and $15.94 \mathrm{~kg} / \mathrm{m} 2$ in two years and exceeded the standard Nadezhda variety by $8.2-7.5 \%$. The maximum seed yield (4.4-4.6 c / ha) was characteristic of the populations Syn downy $S_{1} / S y n$ (c) $S_{1} F_{2}$, Syn (c) $S_{1} /$ Syn downy $S_{1} F_{2}$, Syn (c) $S_{1}$ at free pollination. The Nadezhda and Sinska varieties (standards) have produced seed yields of 2.7 and $3.0 \mathrm{c} / \mathrm{ha}$.

The studies of the inbreeding effect on root characteristics, their connection with the process of nodules formation and other economically valuable features have testified to the following. Second generation inbreeding regardless of the base line root system structure results in increased number of plants with core-branched root system. At the same time, depression is observed in plant height, volume and weight of the root masses. As to the nodule formation, plants reaction is different depending on the genotype, root system form, inbreeding stage. Thus, in the hybrid FHNB population plants with a core-branched root system formed twice as many nodules, while with a core root system - by $51.8 \%$ less compared to the initial forms. Reaction to inbreeding in the Pavlovska 7 variety is different. Regardless of the root system form, the process of nodule formation in the second generation inbreeding progressed 1-4 times more intensively than in the initial forms.

When creating alfalfa varieties with powerful root system, higher nitrogenfixation capacity, selection process has certain peculiarities. Despite the wellknown fact of atmospheric nitrogen fixation by leguminous plants, there are no well-tested methods of measuring this process and no marker characteristics that enable to select forms with maximum values. That is why we tried to find the marker characteristics enabling to assess plants by their nitrogen-fixation capacity at the first stage of the selection process.

The efficiency of the nitrogen biological fixation depends to a considerable extent on the nature of macro and micro symbionts interaction controlled by the host plant $[4,5]$. Given the relevance of this problem for breeding, we conducted a comparative assessment of nitrogen-fixation ability in parent forms and hybrids in the sandy substrate (Table 2). 


\section{Structure of alfalfa populations differing in nitrogen fixation activity}

\begin{tabular}{|c|c|c|c|c|c|c|c|}
\hline \multirow[b]{2}{*}{$\begin{array}{l}\text { Class in activity, } \\
\text { micromol/plant./h }\end{array}$} & \multicolumn{7}{|c|}{ Number of plants, \% } \\
\hline & Sitel & $\begin{array}{l}\text { Sitel/ } \\
\text { Nadezhda } \\
\text { F2 }\end{array}$ & Nadezhda & Gloria & $\begin{array}{l}\text { Gloria/ } \\
\text { Nadezhda } \\
\text { F2 }_{2}\end{array}$ & $\begin{array}{l}\text { ЦП- } \\
11\end{array}$ & $\begin{array}{l}\text { ЦП-11/ } \\
\text { Sitel F2 }\end{array}$ \\
\hline 0.0 & 5.26 & 4.29 & 4.29 & 2.29 & 1.52 & 1.43 & 39.13 \\
\hline $0.01-1.07$ & 71.93 & 42.9 & 71.73 & 65.67 & 6.06 & 28.57 & 43.48 \\
\hline $1.08-2.14$ & 19.30 & 27.14 & 18.57 & 28.36 & 71.24 & 42.86 & 10.14 \\
\hline $2,15-3,21$ & 3,51 & 12,86 & 4,29 & 2,99 & 13,64 & 11,43 & 4,35 \\
\hline $3.22-4.28$ & - & 5.71 & 1.43 & - & 4.55 & 5.71 & - \\
\hline $4.29-5.35$ & - & 4.29 & - & - & 1.52 & 2.86 & - \\
\hline $5.36-6.42$ & - & 2.86 & - & - & 1.52 & 1.43 & - \\
\hline $6.43-7.49$ & - & - & - & - & - & 1.43 & - \\
\hline $7.50-8.56$ & - & - & - & - & - & 1.43 & - \\
\hline $8.57-9.63$ & - & - & - & - & - & 1.43 & - \\
\hline $9.64-10.70$ & - & - & - & - & - & 1.43 & 2.90 \\
\hline
\end{tabular}

The results of the studies on the level of nitrogen-fixation ability have shown that varieties, hybrid populations have the widest variety of genes that control this feature. There are plants that do not fix the nitrogen of the air (1.43-39.13\%). In the majority of cases $53.6-94.0 \%$ plants in the populations have a low nitrogen fixation (0.01-2.14 $\mu \mathrm{mol} /$ plant / h). Their share with an intermediate level of nitrogen activity (2.15-5.35 $\mu \mathrm{mol} / \mathrm{plant} / \mathrm{h})$ was different: in hybrid combinations Sitel / Nadezhda $F_{2}$, CP-11, Gloria / Nadezhda $F_{2}$, it was $22.9-18$, 2\%, in other populations - 2.99-5.72\% of plants.

In the analysis of interstitial variability on the basis of the nitrogen fixation capacity, attention is drawn to the presence of two peaks in the hybrids Sitel / Nadezhda $F_{2}$ and Gloria / Nadezhda $F_{2}$ by the distribution of plants by classes (4.29-6.42 $\mu \mathrm{mol} / \mathrm{plant} / \mathrm{h}$ ). They are absent in their parent form. In this regard the CPU-11 population is of interest: plants are able to bind nitrogen to the maximum, at the same time in some plants this process is absent. In the CS-11 / Sitel $F_{2}$ hybrid after the distribution breakdown (class 3.22-9.63) 2.9\% plants with high nitrogen-fixing ability were registered. This diversity has been reflected in the average values. Hybrid populations with a large number of plants that had high nitrogen-fixing rates had high average values.

It is known that the degree of characteristic expression in descendants can be predicted by the heredity character. When crossing alfalfa plants contrasting in nitrogen fixation, the increased ability of plants to fix air nitrogen dominates. Therefore, parental forms with different levels of nitrogenase activity were taken for crossing. Depending on the genetic components of the crossing, the nitrogenfixing activity was transmitted to the descendants in different ways and the nature of its inheritance was determined by their genetic components and the action and interaction of the genes that control this characteristic. Depending on the genetic cross-linking component, the nitrogen-fixing ability was inherited by the type of incomplete positive $\left(h_{p}+0.23+0.64\right)$ and intermediate dominance $\left(h_{p}=+0.08\right)$. In 
hybrid populations (Gloria / Nadezhda $F_{2}$ and Sitel / Naddezhda $F_{2}$ ) with incomplete positive dominance, plants are superior to the best father's nitrogenase activity, by 83.7 and $137.2 \%$, respectively, while with the intermediate inheritance the hybrid CP-11 / Sitel $\mathrm{F}_{2}$ is inferior to the parental form by $80.8 \%$ (Table 3).

\section{Nitrogen fixation activity in various alfalfa populations}

\begin{tabular}{|l|l|l|l|l|l|l|}
\hline $\begin{array}{l}\text { Variety, hybrid } \\
\text { population }\end{array}$ & $\mathrm{n}$ & $\mathrm{x} \pm \mathrm{S}_{\mathrm{x}}$ & $\sigma^{2}$ & $\mathrm{v}, \%$ & $\lim$ & $\mathrm{h}_{\mathrm{p}}$ \\
\hline Gloria $q$ & 57 & $0.70 \pm 0.225$ & 2.87 & 72.2 & $0.13-2.20$ & \\
\hline Gloria / Nadezhda $\mathrm{F}_{2}$ & 70 & $1.58 \pm 0.470$ & 15.80 & 79.5 & $0.13-5.82$ & +0.23 \\
\hline Nadezhda ${ }^{\wedge}$ & 70 & $0.86 \pm 0.081$ & 0.46 & 79.0 & $0.06-4.17$ & \\
\hline Sitel $q$ & 67 & $0.80 \pm 0.265$ & 3.12 & 69.4 & $0.05-2.43$ & \\
\hline Sitel / Nadezhda $\mathrm{F}_{2}$ & 67 & $2.04 \pm 0.479$ & 14.90 & 59.8 & $0.57-8.14$ & +0.64 \\
\hline $\mathrm{CP}-11 q$ & 70 & $2,03 \pm 0,730$ & 37,80 & 95,8 & $0,05-8,80$ & \\
\hline $\mathrm{CP}-11 /$ Sitel $\mathrm{F}_{2}$ & 70 & $1.64 \pm 0.700$ & 34.40 & 113.2 & $0.10-10.90$ & +0.08 \\
\hline
\end{tabular}

The study of correlation dependencies makes it possible to determine the factorial features that can serve as criteria for the selection of nitrogen fixation capacity. Our studies have shown that there is a correlation between nitrogen fixation and morphological features, the total number of nodules and their fractional composition. The experimental data obtained suggest that the level of nitrogen-fixation activity depends (33.6-98.0\%) on the quantitative composition of the nodules larger than $1 \mathrm{~mm}$. Such morphological features of the nodule forming process as the total number of nodules larger than $1 \mathrm{~mm}$, their coloring and location in the root system can be used as markers. Visual monitoring of their use is very important for the initial evaluation at the beginning of selection and can be used for negative selection - the removal of plants with low nitrogen fixation capacity.

\section{Conclusion}

Comprehensive assessment of the collection material under irrigation has enabled selecting forms that are of interest as a base line for the selection of new high-yield alfalfa varieties with different characteristics and properties.

Marker features have been identified that enable selecting forms with maximum nitrogen fixation rates at the first stages of the selection process.

\section{Bibliography}

1. Tarariko O.H. Kontseptsiya i naukove obgruntuvannya osnovnykh napryamkiv udoskonalennya system vypusku i realizatsiyi mikrobiolohichnykh preparativ dlya sil's'kohospodars'koho vyrobnytstva/O.H. Tarariko, O.V. Sherstoboyeva, V.P. Patyka//Mikrobiol. zhurn. - 1997. — \# 4. - S. 102 - 108.

2. Vidtvorennya humusu v ahroekosystemakh Polissya/V.P. Strel'chenko, A.T. Bovsunovs'kyy, O.P. Stetsyuk ta in.//Visn. ahrar. nauky. — 2000. — \# 7. — S. $9-13$.

3. Tuev N.A. Эkolohycheskye problemы yntensyvnoho zemledelyya/N.A. Tuev//Vestn. s.-kh. nauky. — 1988. — \# 6. — S. 91 - 93. 
4. Lozovits'kyy P.S. Popovnennya humusu u gruntakh Inhulets'koyi zroshuval'noyi systemy za rakhunok korenevykh zalyshkiv sil's'kohospodars'kykh kul'tur/P.S. Lozovits'kyy//Zroshuvane zemlerobstvo. — Kherson: Aylant, 2010. — \# 54. — S. $198-210$.

5. Lыmar' A.O. Эkolohycheskye osnovы systemы oroshaemoho zemledelyya/A.O. Lыmar'. — K.: Ahrar. nauka, 1997. — 400 s.

6. Tyshchenko O.D. Metodyka selektsiyi lyutserny na pidvyshchenyy riven' symbiotychnoyi azotfiksatsiyi/O.D. Tyshchenko, A.V. Tyshchenko. — Kherson, 2016. - $19 \mathrm{~s}$.

7. Lubenets P.A. Lyutserna - Medicago L. (kratkyy obzor roda y klassyfykatsyya podroda Falcago (Rchb.) Crossh.)/P.A. Lubenets//Tr. po prykladnoy botanyke, henetyke y selektsyy. — L., 1972. - T. 47. - Vыp. 3. - S. 3 - 82.

8. Shevtsov Y.A. Yspol'zovanye ynbrydynha u rastenyy/Y.A. Shevtsov. - K.: Nauk. dumka, 1983. - 270 s.

9. Smetanyn N.Y. Struktura populyatsyy lyutsernы (Medicago sativa L.) po urovnyu azotfyksatsyy/N.Y. Smetanyn, V.K. Shumndy//Sybyrsk. vestn. s.-kh. nauky. - 1982. — \# 6. - S. 38 - 43.

10. Tykhonovych Y.A. Эkoloho-henetycheskye osnovы yspol'zovanyya byoraznoobrazyya symbyotycheskykh system dlya povыshenyya produktyvnosty rastenyy $\mathrm{v}$ uslovyyakh эkolohychesky ustoychyvoho zemledelyya/Y.A. Tykhonovych, N.A. Provorov//Mater. mezhdunar. ahroprom. konhressa Ahrorus'. Ynnovatsyy — osnova razvytyya ahroprombshlennoho kompleksa. - SPb.: Lenэkspo, 2010. - S. 38 - 61.

11. Spaink H. The Rhizobiaceae. Molecular biology of model plant — associated bacteria/H. Spaink, A. Kondorosi, P. Hooykaas; per. s anhl. pod red. Y.A. Tykhonovycha y N.A. Provorova. — SPb., 2002. — S. 376 - 561. 